\title{
PENGEMBANGAN BAHAN AJAR PENDIDIKAN AGAMA ISLAM MELALUI MULTIMEDIA PADA MATERI SYAJA'AH KELAS XI DI SMA NEGERI 4 BANDUNG
}

\author{
Jajang Eris Hermana ${ }^{1}$, dan Mismit Husen ${ }^{2)}$ \\ 1) Mahasiswa Program Studi Pendidikan Agama Islam Pasca Sarjana, UIN Sunan \\ Gunung Djati, Jl. Cimencrang (Soekarno-Hatta) Kel. Cimencrang \\ Kec. Gedebage Kota Bandung 40294. \\ Email: jajang_bdg13@yahoo.com \\ 2) Mahasiswa Program Studi Pendidikan Agama Islam Pasca Sarjana, UIN Sunan \\ Gunung Djati, Jl. Cimencrang (Soekarno-Hatta) Kel. Cimencrang \\ Kec. Gedebage Kota Bandung 40294. \\ Email: mismithusen88@gmail.com
}

\begin{abstract}
Abstrak : Bahan ajar adalah segala bentuk bahan yang digunakan untuk membantu guru/instruktor dalam melaksanakan kegiatan belajar mengajar. Bahan yang dimaksud bisa berupa bahan tertulis maupun bahan tidak tertulis. Dengan bahan ajar memungkinkan siswa dapat mempelajari suatu kompetensi atau kompetensi dasar secara runtut dan sistematis sehingga secara akumulatif mampu menguasai semua kompetensi secara utuh dan terpadu. Di era digital seperti sekarang ini, maka bahan ajar dalam pembelajaran Pendidikan Agama Islam perlu dikembangkan, sehingga para siswa tidak ketinggalan zaman. Pengembangan bahan ajar ini disebut bahan ajar multimedia. Dengan adanya multimedia ini diharapkan mampu menemukan temuan baru untuk dipelajari. Bahan ajar multimedia ini dalam menyiapkannya diperlukan pengetahuan dan keterampilan pendukung yang memadai terutama dalam mengoperasikan peralatan seperti komputer, kamera, video, dan kamera foto. Teknik penyusunan bahan ajar meliputi analisis SK-KD-Indikator, analisis sumber belajar, pemilihan dan penentuan bahan ajar, dan mengembangkan bahan ajar. Sebuah bahan ajar paling tidak mencaku petunjuk belajar (petunjuk siswa/guru), kompetensi yang akan dicapai, content atau isi materi pembelajaran, informasi pendukung, dan latihan-latihan.
\end{abstract}

Kata kunci:

Pengembangan, Pendidikan Agama Islam, Multimedia

\begin{abstract}
Teaching materials are all forms of materials used to assist teachers / instructors in carrying out teaching and learning activities. The material in question can be either written materials or unwritten materials. With teaching materials allows students to learn a competence or basic competence in a coherent and systematic so that the accumulative able to master all the competencies as a whole and integrated. In the digital era like today, the teaching materials in learning Islamic Religious Education need to be developed, so the students are not behind the times. Development of teaching materials is called multimedia teaching materials. With this multimedia is expected to find new findings to learn. This multimedia teaching materials in preparing it required adequate knowledge and support skills, especially in operating equipment such as computers, cameras, video, and photo cameras. Technique of preparation of instructional materials include SK-KD-Indicator analysis, analysis of learning resources, selection and determination of teaching materials, and developing teaching materials. A teaching material at least does not include instructional instructions (student manual / teacher), competence to be achieved, content or content of learning materials, supporting information, and exercises.
\end{abstract}

Keywords:

Development, Islamic Education, Multimedia 


\section{PENDAHULUAN}

Proses pembelajaran selain diawali dengan perencanaan yang bijak, serta didukung dengan komunikasi yang baik, juga harus didukung dengan pengembangan strategi yang mampu membelajarkan siswa. Pengelolaan pembelajaran merupakan suatu proses penyelenggaraan interaksi peserta didik dengan pendidik dan sumber belajar pada suatu lingkungan belajar.

Pengajaran adalah operasionalisasi dari kurikulum. Pengajaran disekolah terjadi apabila terjadi interaksi antara siswa dengan lingkungan belajar yang diatur guru untuk mencapai tujuan ajaran. Komponen lain di samping tujuan adalah menetapkan bahan ajaran dan kegiatan belajar-mengajar. Bahan pelajaran dirumuskan setelah tujuan ditetapkan. Bahan pelajaran harus disusun sedemikian rupa agar dapat menunjang tercapainya tujuan pengajaran. Sedangkan kegiatan belajar mengajar ditetapkan berdasarkan tujuan dan bahan pelajaran.

Bahan ajar untuk pembelajaran koginitif (pengetahuan) akan berwujud teori-teori atau konsep-konsep keilmuan. Bahan ajar untuk pembelajaran psikomotorik (keterampilan) akan berwujud cara atau prosedur mengerjakan dan menyelesiakan sesuatu. Sedangkan bahan ajar untuk pembelajaran afektif (sikap) akan berwujud nilainilai atau norma-norma. Jadi, sebagai calon pendidik nantinya Anda harus mampu memilih bahan ajar menyangkut dengan aspek yang dipelajari siswa harus memenuhi ranah koginitif, psikomotorik, dan afektif.

\section{LANDASAN TEORI}

Bahan ajar adalah segala bentuk bahan yang tertulis seperti buku, majalah, koran, LCD proyektor, maupun bahan yang tidak tertulis seperti kaset, radio, film dan lain sebagainya yang digunakan oleh para guru dalam melaksanakan kegiatan belajar.

Menurut Tim Siosialisasi KTSP, bahan ajar adalah segala bentuk bahan yang digunakan untuk membantu guru/instruktur dalam melaksanakan kegiatan belajar mengajar di kelas. Bahan yang dimaksud bisa berupa bahan tertulis maupun bahan tidak tertulis. Sedangkan menurut Ahmad Sudrajat, bahan ajar adalah seperangkat materi yang disusun secara sistematis baik tertulis maupun tidak tertulis sehingga tercipta lingkungan/suasana yang memungkinkan siswa untuk belajar.

Bahan ajar atau materi pelajaran secara garis besar terdiri dari pengetahuan, keterampilan, dan sikap yang harus dipelajari siswa dalam rangka mencapai standar kompetensi yang telah ditentukan. Secara terperinci, jenis-jenis materi pembelajaran terdiri dari pengetahuan (fakta, prinsip, konsep, prosedur), keterampilan, dan sikap atau nilai yang harus dipelajari siswa dalam rangka mencapai standar kompetensi yang telah ditentukan. Bahan ajar disusun dengan tujuan

a. Menyediakan bahan ajar yang sesuai dengan tuntutan kurikulum dengan mempertimbangkan kebutuhan siswa, yakni bahan ajar yang sesuai dengan karakteristik dan setting atau lingkungan sosial siswa. 
b. Membantu siswa dalam memperoleh alternatif bahan ajar di samping buku-buku teks yang terkadang sulit diperoleh.

c. Memudahkan guru dalam melaksanakan pembelajaran.

Ada sejumlah manfaat yang dapat diperoleh apabila seorang guru mengembangkan bahan ajar sendiri, yakni antara lain; pertama, diperoleh bahan ajar yang sesuai tuntutan kurikulum dan sesuai dengan kebutuhan belajar siswa, kedua, tidak lagi tergantung kepada buku teks yang terkadang sulit untuk diperoleh, ketiga, bahan ajar menjadi labih kaya karena dikembangkan dengan menggunakan berbagai referensi, keempat, menambah khasanah pengetahuan dan pengalaman guru dalam menulis bahan ajar, kelima, bahan ajar akan mampu membangun komunikasi pembelajaran yang efektif antara guru dengan siswa karena siswa akan merasa lebih percaya kepada gurunya.

Di samping itu, guru juga dapat memperoleh manfaat lain, misalnya tulisan tersebut dapat diajukan untuk menambah angka kredit ataupun dikumpulkan menjadi buku dan diterbitkan. Dengan tersedianya bahan ajar yang bervariasi, maka siswa akan mendapatkan manfaat yaitu, kegiatan pembelajaran menjadi lebih menarik. Siswa akan lebih banyak mendapatkan kesempatan untuk belajar secara mandiri dan mengurangi ketergantungan terhadap kehadiran guru. Siswa juga akan mendapatkan kemudahan dalam mempelajari setiap kompetensi yang harus dikuasainya.

\section{A. Prinsip Pengembangan Bahan Ajar}

Pengembangan bahan ajar hendaklah memperhatikan prinsisp-prinsip pembelajaran. Di antara prinsip pembelajaran tersebut adalah:

1. Mulai dari yang mudah untuk memahami yang sulit, dari yang kongkret untuk memahami yang abstrak

Siswa akan lebih mudah memahami suatu konsep tertentu apabila penjelasan dimulai dari yang mudah atau sesuatu yang kongkret, sesuatu yang nyata ada di lingkungan mereka. Misalnya untuk menjelaskan konsep pasar, maka mulailah siswa diajak untuk berbicara tentang pasar yang terdapat di tempat mereka tinggal. Setelah itu, kita bisa membawa mereka untuk berbicara tentang berbagai jenis pasar lainnya.

2. Pengulangan akan memperkuat pemahaman

Dalam pembelajaran, pengulangan sangat diperlukan agar siswa lebih memahami suatu konsep. Walaupun maksudnya sama, sesuatu informasi yang diulang-ulang, akan lebih berbekas pada ingatan siswa. Umpan balik positif akan memberikan penguatan terhadap pemahaman siswa.

3. Umpan balik positif akan memberikan penguatan terhadap pemahaman siswa Seringkali kita menganggap enteng dengan memberikan respond yang sekedarnya atas hasil kerja siswa. Padahal respond yang diberikan oleh guru terhadap siswa akan menjadi penguatan pada diri siswa.

4. Motivasi belajar yang tinggi merupakan salah satu faktor penentu keberhasilan belajar 
Seorang siswa yang memiliki motivasi belajar tinggi akan lebih berhasil dalam belajar. Untuk itu, maka salah satu tugas guru dalam melaksanakan pembelajaran adalah memberikan dorongan (motivasi) agar siswa mau belajar.

5. Mencapai tujuan ibarat naik tangga, setahap demi setahap, akhirnya akan mencapai ketinggian tertentu

Pembelajaran adalah suatu proses yang bertahap dan berkelanjutan. Untuk mencapai suatu standard kompetensi yang tinggi, perlu dibuatkan tujuan-tujuan antara.

6. Mengetahui hasil yang telah dicapai akan mendorong siswa untuk terus mencapai tujuan

Dalam proses pembelajaran, guru ibarat pemandu perjalanan. Dengan demikian, semua peserta dapat mencapai kota tujuan dengan selamat. Dalam pembelajaran, setiap anak akan mencapai tujuan tersebut dengan kecepatannya sendiri, namun mereka semua akan sampai kepada tujuan meskipun dengan waktu yang berbeda-beda. Inilah sebagian dari prinsip belajar tuntas.

Pembelajaran adalah suatu proses yang bertahap dan berkelanjutan. Untuk mencapai suatu standard kompetensi yang tinggi, perlu dibuatkan tujuan-tujuan antara. Ibarat anak tangga, semakin lebar anak tangga semakin sulit kita melangkah, namun juga anak tangga yang terlalu kecil terlampau mudah melewatinya. Untuk itu, maka guru perlu menyusun anak tangga tujuan pembelajaran secara pas, sesuai dengan karakteristik siswa. Dalam bahan ajar, anak tangga tersebut dirumuskan dalam bentuk indikatorindikator kompetensi.

Dalam mengembangkan bahan ajar tentu perlu memperhatikan prinsisp-prinsip pembelajaran.Gafur (1994) menjelaskan bahwa beberapa prinsip yang perlu diperhatikan dalam penyusunan bahan ajar atau materi pembelajaran diantaranya meliputi prinsip relevansi, konsistensi, dan kecukupan. Ketiga penerapan prinsip-prinsip tersebut dipaparkan sebagai berikut:

1. Prinsip relevansi, artinya keterkaitan. Materi pembelajaran hendaknya relevan atau ada kaitan atau ada hubungannya dengan pencapaian SK dan KD. Cara termudah ialah dengan mengajukan pertanyaan tentang kompetensi dasar yang harus dikuasai siswa. Dengan prinsip dasar ini, guru akan mengetahui apakah materi yang hendak diajarkan tersebut materi fakta, konsep, prinsip, prosedur, aspek sikap atau aspek psikomotorik sehingga pada gilirannya guru terhindar dari kesalahan pemilihan jenis materi yang tidak relevan dengan pencapaian SK dan KD.

2. Prinsip konsistensi, artinya keajegan. Artinya ada kesesuaian (jumlah/banyaknya) antara kompetensi dan bahan ajar; jika kompetensi dasar yang ingin dibelajarkan mencakup keempat keterampilan berbahasa, bahan yang dipilih/dikembangkan juga mencakup keempat hal itu.

3. Prinsip kecukupan, artinya materi yang diajarkan hendaknya cukup memadai dalam membantu siswa menguasai kompetensi dasar yang diajarkan. Materi tidak boleh terlalu sedikit, dan tidak boleh terlalu banyak. Jika terlalu sedikit 
akan kurang membantu mencapai SK dan KD. Sebaliknya, jika terlalu banyak akan membuang-buang waktu dan tenaga yang tidak perlu untuk mempelajarinya.

Materi pelajaran berada dalam ruang lingkup isi kurikulum. Karena itu, pemilihan bahan ajar tentu saja harus sejalan dengan ukuran-ukuran (kriteria) yang digunakan untuk memilih isi kurikulum bidang studi bersangkutan. Adapun kriteria pemilihan bahan ajar antara lain:

a. Kriteria tujuan instruksional

Suatu materi pelajaran yang terpilih dimaksudkan untuk mencapai tujuan instruksional khusus atau tujuan-tujuan tingkah laku. Karena itu, materi tersebut supaya sejalan dengan tujuan-tujuan yang dirumuskan.

b. Materi pelajaran supaya terjabar

Perincian materi pelajaran berdasarkan pada tuntunan dimana setiap TIK telah dirumuskan secara spesifik, dapat diamati dan terukur. Ini berarti terdapat keterkaitan yang erat antara spesifikasi tujuan dan spesifikasi materi pelajaran.

c. Relevan dengan kebutuhan siswa

Kebutuhan siswa yang pokok adalah bahwa mereka ingin berkembang berdasarkan potensi yang dimilikinya. Karena setiap materi pelajaran yang akan disajikan hendaknya sesuai dengan usaha untuk mengembangkan pribadi siswa secara bulat dan utuh. Beberapa aspek diantaranya adalah pengetahuan sikap, nilai, dan keterampilan.

d. Kesesuaian dengan kondisi masyarakat

Siswa dipersiapkan untuk menjadi warga masyarakat yang berguna dan mampu hidup mandiri. Dalam hal ini, materi pelajaran yang dipilih hendaknya turut membantu mereka memberikan pengalaman edukatif yang bermakna bagi perkembangan mereka menjadi manusia yang mudah menyesuaikan diri.

e. Materi pelajaran mengandung segi-segi etik

Materi pelajaran yang akan dipilih hendaknya mempertimbangkan segi perkembangan moral siswa kelak. Pengetahuan dan keterampilan yang bakal mereka peroleh dari materi pelajaran yang telah mereka terima diarahkan untuk mengembangkan dirinya sebagai manusia yang etik sesuai dengan sistem nilai dan norma-norma yang berlaku di masyarakatnya.

f. Materi pelajaran tersusun dalam ruang lingkup dan urutan yang sistematik dan logis

Setiap materi pelajaran disusun secara bulat dan menyeluruh, terbatas ruang lingkupnya dan terpusat pada satu topik masalah tertentu. Materi disusun secara berurutan dengan mempertimbangkan faktor perkembangan psikologis siswa. Dengan cara ini diharapkan isi materi tersebut akan lebih mudah diserap oleh siswa dan dapat segera dilihat keberhasilannya.

g. Materi pelajaran bersumber dari buku sumber yang baku, pribadi guru yang ahli, dan masyarakat 
Ketiga faktor ini perlu diperhatikan dalam memilih materi pelajaran. Buku sumber yang baku umumnya disusun oleh para ahli dalam bidangnya dan disusun berdasarkan GBPP yang berlaku, kendatipun belum tentu lengkap sebagaimana yang diharapkan. Guru yang ahli penting, oleh sebab sumber utama memang adalah guru itu sendiri. Guru dapat menyimak semua hal yang dianggapnya perlu untuk disajikan kepada para siswa berdasarkan ukuran pribadinya. Masyarakat juga merupakan sumber yang luas, bahkan dapat dikatakan sebagai materi belajar yang paling besar.

Secara umum bahan ajar dapat dibedakan ke dalam bahan ajar cetak dan noncetak. Bahan ajar cetak dapat berupa, handout, buku, modul, brosur, dan lembar kerja siswa. Sedangkan bahan ajar noncetak meliputi, bahan ajar audio seperti, kaset, radio, piringan hitam, dan compact disc audio. Bahan ajar audio visual seperti, CAI (Computer Assisted Instruction), dan bahan ajar berbasis web (web based learning materials) (Ika Lestari, 2013: 5).

Lebih lanjut Mulyasa (2006: 96) menambahkan bahwa bentuk bahan ajar atau materi pembelajaran antara lain adalah bahan cetak (hand out, buku, modul, LKS, brosur, dan leaflet), audio (radio, kaset, cd audio), visual (foto atau gambar), audio visual (seperti; video/ film atau VCD) dan multi media (seperti; CD interaktif, computer based, dan internet).

Bahan ajar yang dimaksud dalam kajian ini lebih ke bahan ajar cetak berupa buku teks. Hal ini dikarenakan, buku teks sangat erat kaitannya dengan kurikulum, silabus, standard kompetensi, dan kompetensi dasar. Rudi Susilana (2007: 14) mengungkapkan bahwa buku teks adalah buku tentang suatu bidang studi atau ilmu tertentu yang disusun untuk memudahkan para guru dan siswa dalam upaya mencapai tujuan pembelajaran.

Untuk lebi jelasnya, bahwa bentuk-bentuk bahan ajar atau materi pembelajaran antara lain:

a. Bahan ajar cetak (Printed)

Bahan ajar cetak dapat ditampilkan dalam berbagai bentuk. Jika bahan ajar cetak tersusun secara baik maka bahan ajar akan mendatangkan beberapa keuntungan seperti yang dikemukakan oleh Steffen Peter Ballstaedt, (1994) yaitu:

1. Bahan tertulis biasanya menampilkan daftar isi, sehingga memudahkan bagi seorang guru untuk menunjukkan kepada peserta didik bagian mana yang sedang dipelajari.

2. Biaya untuk pengadaannya relatif sedikit.

3. Bahan tertulis cepat digunakan dan dapat dipindah-pindah secara mudah.

4. Susunannya menawarkan kemudahan secara luas dan kreativitas bagi individu.

5. Bahan tertulis relatif ringan dan dapat dibaca di mana saja.

6. Bahan ajar yang baik akan dapat memotivasi pembaca untuk melakukan aktivitas, seperti menandai, mencatat, membuat sketsa

7. Bahan tertulis dapat dinikmati sebagai sebuah dokumen yang bernilai besar

8. Pembaca dapat mengatur tempo secara mandiri 
Menurut Bandono (2009) penyusunan bahan ajar cetak memperhatikan hal-hal sebagai berikut:

a) Susunan tampilan

b) Bahasa yang mudah

c) Menguji pemahaman

d) Stimulan

e) Kemudahan dibaca

f) Materi instruksional

Banyak sekali jenis bahan ajar cetak yang bisa digunakan dalam proses pembelajaran, antara lain adalah handout, modul, buku teks, lembar kegiatan siswa, model (maket), poster dan brosur.

1. Handout

Menurut Andi Prastowo handout merupakan bahan pembelajaran yang sangat ringkas, bersumber dari beberapa literatur yang relevan terhadap kompetensi dasar dan materi pokok yang diajarkan kepada peserta didik. Pada umumnya handout berfungsi untuk membantu peserta didik agar tidak perlu mencatat, sebagai pendamping penjelasan pendidik, sebagai bahan rujukan peserta didik, memotivasi peserta didik agar lebih giat belajar, pengingat pokok-pokok materi yang diajarkan, memberi umpan balik dan menilai hasil belajar.

2. Modul

Modul adalah sebuah buku yang ditulis dengan tujuan agar peserta didik dapat belajar secara mandiri tanpa atau dengan bimbingan guru, sehingga modul berisi paling tidak tentang:

a. Petunjuk belajar (Petunjuk siswa/guru)

b. Kompetensi yang akan dicapai

c. Content atau isi materi

d. Informasi pendukung

e. Latihan-latihan

f. Petunjuk kerja, dapat berupa Lembar Kerja (LK)

g. Evaluasi

h. Balikan terhadap hasil evaluasi

Pembelajaran dengan modul juga memungkinkan peserta didik yang memiliki kecepatan tinggi dalam belajar akan lebih cepat menyelesaikan satu atau lebih kompetensi dasar dibandingkan dengan peserta didik lainnya. Selain itu, juga meningkatkan kemampuan peserta didik untuk belajar sendiri tanpa tergantung kepaga kehadiran pendidik.

\section{Buku Teks}

Buku teks pelajaran pada umumnya merupakan bahan tertulis yang menyajikan ilmu pengetahuan atau buah pikiran dari pengarangnya yang disusun secara sistematis berdasarkan kurikulum yang berlaku. Buku teks berguna untuk membantu pendidik dalam melaksanakan kurikulum karena disusun berdasarkan kurikulum yang berlaku, menjadi pegangan guru dalam menentukan metode pengajaran dan memberikan 
kesempatan bagi peserta didik untuk mengulangi pelajaran atau mempelajari pelajaran baru.

\section{Lembar Kegiatan Siswa}

Lembar kegiatan siswa (student work sheet) adalah lembaran-lembaran berisi tugas yang harus dikerjakan oleh peserta didik. Lembar kegiatan biasanya berupa petunjuk atau langkah-langkah untuk menyelesaikan suatu tugas. Suatu tugas yang diperintahkan dalam lembar kegiatan harus jelas kompetensi dasar yang akan dicapainya. LKS berfungsi untuk meminimalkan peran pendidik dan mengaktifkan peran peserta didik, mempermudah peserta didik untuk memahami materi yang diberikan dan kaya akan tugas untuk berlatih.

\section{Model (Maket)}

Model (maket) merupakan bahan ajar yang berupa tiruan benda nyata untuk menjembatani berbagai kesulitan yang bisa ditemui, apabila menghadirkan objek atau benda tersebut langsung ke dalam kelas, sehingga nuansa asli dari benda tersebut masih bisa dirasakan oleh peserta didik tanpa mengurangi struktur aslinya, sehingga pembelajaran menjadi lebih bermakna

\section{Brosur}

Brosur adalah bahan informasi tertulis mengenai suatu masalah yang disusun secara bersistem atau cetakan yang hanya terdiri atas beberapa halaman dan dilipat tanpa dijilid atau selebaran cetakan yang berisi keterangan singkat tetapi lengkap tentang perusahaan atau organisasi (Kamus besar Bahasa Indonesia, Edisi Kedua, Balai Pustaka, 1996). Dengan demikian, maka brosur dapat dimanfaatkan sebagai bahan ajar, selama sajian brosur diturunkan dari kompetensi dasar yang harus dikuasai oleh siswa. Mungkin saja brosur dapat menjadi bahan ajar yang menarik, karena bentuknya yang menarik dan praktis. Agar lembaran brosur tidak terlalu banyak, maka brosur didesain hanya memuat satu kompetensi dasar saja. Ilustrasi dalam sebuah brosur akan menambah menarik minat peserta didik untuk menggunakannya.

\section{Foto/Gambar}

Bahan ajar tentu saja diperlukan satu rancangan yang baik agar setelah selesai melihat sebuah atau serangkaian foto/gambar siswa dapat melakukan sesuatu yang pada akhirnya menguasai satu atau lebih kompetensi dasar.

Menurut Weidenmann dalam buku Lehren mit Bildmedien menggambarkan bahwa melihat sebuah foto/gambar lebih tinggi maknanya dari pada membaca atau mendengar. Melalui membaca yang dapat diingat hanya 10\%, dari mendengar yang diingat 20\%, dan dari melihat yang diingat 30\%. Foto/gambar yang didesain secara baik dapat memberikan pemahaman yang lebih baik. Bahan ajar ini dalam menggunakannya harus dibantu dengan bahan tertulis. Bahan tertulis dapat berupa petunjuk cara menggunakannya dan atau bahan tes

\section{b. Bahan Ajar Dengar (Audio)}

Bahan ajar audio merupakan salah satu bahan ajar noncetak yang didalamnya mengandung suatu sistem yang menggunakan sinyal audio secara langsung, yang dapt dimainkan atau diperdengarkan oleh pendidik kepada peserta didiknya guna membantu 
mereka menguasai kompetensi tertentu. Jenis-jenis bahan ajar audio ini antara lain adalah radio, kaset MP3, MP4, sounds recorder dan handphone. Bahan ajar ini mampu menyimpan suara yang dapat diperdengarkan secara berulang-ulang kepada peserta didik dan biasanya digunakan untuk pelajaran bahasa dan musik.

c. Bahan Ajar Pandang Dengar (Audiovisual)

Bahan ajar pandang dengar merupakan bahan ajar yang mengombinasikan dua materi, yaitu visual dan auditif. Materi auditif ditujukan untuk merangsang indra pendengaran sedangkan visual untuk merangsang indra penglihatan. Dengan kombinasi keduanya, pendidik dapat menciptakan proses pembelajaran yang lebih berkualitas. Hal itu berdasarkan bahwa peserta didik cenderung akan lebih mudah mengingat dan memahami suatu pelajaran jika mereka tidak hanya menggunakan satu jenis indra saja, apalagi jika hanya indra pendengaran saja.

Bahan ajar pandang dengar mampu memperlihatkan secara nyata sesuatu yang pada awalnya tidak mungkin bisa dilihat di dalam kelas menjadi mungkin dilihat. Selain itu juga dapat membuat efek visual yang memungkinkan peserta didik memperkuat proses belajar. Bahan ajar pandang dengar antara lain adalah video dan film.

d. Bahan Ajar Interaktif (Interactive Teaching Material)

Bahan ajar interaktif adalah bahan ajar yag mengombinasikan beberapa media pembelajaran (audio, video, teks atau grafik) yang bersifat interaktif untuk mengendalikan suatu perintah atau perilaku alami dari suatu presentasi. Bahan ajar interaktif memungkinkan terjadinya hubungan dua arah antara bahan ajar dan penggunanya, sehinnga peserta didik akan terdorong untuk lebih aktif.

Bahan ajar interaktif dapat ditemukan dalam bentuk CD interaktif, yang dalam proses pembuatan dan penggunaannya tidak dapat trelepas dari perangkat komputer. Maka dari itu, bahan ajar interaktif juga termasuk bahan ajar berbasis komputer.

\section{METODOLOGI PENELITIAN}

Dalam penelitian ini menggunakan penelitian pustaka (libraryresearch). Penelitian ini bertujuan untuk mengumpulkan data dan informasi dengan bantuan bermacam-macam material yang terdapat di ruangan perpustakaan, seperti: buku-buku, majalah, dokumen, catatan dan kisah kisah sejarah dan lainnya. Pada hakikatnya data yang diperoleh dengan penelitian perpustakaan ini dapat dijadikan landasan dasar dan alat utama bagi pelaksanaan penelitian lapangan. Penelitian ini dikatakan juga sebagai penelitian yang membahas data-data sekunder.

Riset pustaka tentu saja bukan sekadar membaca dan mencatat literatur atau bukubuku sebagaimana yang dipahami oleh orang selama ini. Yang disebut riset kepustakaan atau yang sering juga disebut studi pustaka, ialah serangkaian kegiatan yang berkenaan dengan metode pengumpulan data pustaka, membaca dan mencatat serta mengolah bahan penelitian.

Sedangkan teknik pengumpulan data yang digunakan dalam penulisan skripsi ini adalah teknik dokumentasi.Dokumentasi adalah mencari data mengenai hal-hal atau variable yang berupa catatan,transkip, buku. Dalam melaksanakan teknik dokumentasi 
ini penulis melakukan penelitian terhadap benda-benda tertulis yaitu buku-buku, catatan-catatan dan lain-lain.

\section{TEMUAN DAN PEMBAHASAN}

SMA Negeri 4 Bandung, merupakan salah satu Sekolah Menengah Atas Negeri yang ada di Kota Bandung Provinsi Jawa Barat, Indonesia. Sama dengan SMA pada umumnya di Indonesia masa pendidikan sekolah di SMA Negeri 4 Bandung ditempuh dalam waktu tiga tahun pelajaran, mulai dari Kelas X sampai Kelas XII. SMA Negeri 4 didirikan pada tahun 1963. Pada tahun 2017 SMA Negeri 4 Bandung pernah meraih juara sekolah terbaik religi ke 1 tingkat Kota Bandung.

Pada awal berdirinya, sekolah ini bernama Sekolah Menengah Atas Parki yang berbantuan sebagai sekolah swasta yang beralamat di Jalan Pasundan. Pada tanggal 1 Agustus 1950, Pemerintah melalui Dinas Pendidikan dan Kebudayaan mengubah nama dan status SMA Parki menjadi SMA Negeri 3 A/B Bandung (pada waktu itu ada tiga SMA Negeri di Bandung, yaitu SMA 1 B/C dan SMA 2 B/C di Jl. Belitung, dan SMA 3 A/B Jl. Sumatera 36A Bandung) yang terbagi menjadi dua yaitu SMA 3 Bandung Bagian A yang dipimpin oleh Bapak R.I. Karta Dipraja, sedangkan bagian B dipimpin olah Bapak Nawawi. Tahun pelajaran 1953/1954 SMA Negeri 3 A/B Bandung berpindah ke Jalan Sumatra, menumpang di SMP Negeri 2 Bandung dan SMP Negeri 5 Bandung.

Pada tahun pelajaran 1956/1957 sekolah tersebut berganti nama. SMA Negeri 3A menjadi SMA Negri IA Bandung, SMA Negeri 3B menjadi SMA Negri IVB Bandung. SMA Negri IA Bandung selanjutnya menjadi SMA Negeri I yang sekarang disebut SMA Negeri 1 Bandung. SMA Negri IVB Bandung selanjutnya menjadi SMA Negeri IV yang sekarang disebut SMA Negeri 4 Bandung.

Di bawah pimpinan Bapak Drs. Saban Bratakusumah pada tanggal 12 Juli 1966 SMA Negeri 4 Bandung beralih tempat, menempati gedung bekas SD Chung Hwi di Jalan Gardujati No.20 Bandung hingga sekarang. Pada tahun itu juga terjadi pergantian pimpinan dari Bapak Drs Saban Bratakusumah kepada Bapak R. Darjanto Djojosugito.

Di beberapa tahun sebelumnya, SMA Negeri 4 Bandung berada di bawah naungan Dinas Pendidikan Kota Bandung. Namun, sejak awal tahun 2017 SMA Negeri 4 Bandung diambil alih dan dikelola oleh Dinas Pendidikan Jawa Barat, begitu pun dengan SMA/SMK se Jawa Barat baik negeri maupun swasta. Oleh karena itu, segala koordinasi selalu berhubungan dengan Dinas Pendidikan Jawa Barat.

Sebagaimana materi syaja'ah yang sudah dijelaskan di atas, bahwa di era digital sekarang ini sudah praktis dan penuh dengan inofasi untuk mengembangan bahan ajar PAI sehingga siswa tidak merasa bosan, bahan dalam proses pembalajaran akan merasa senang dan menarik. Adapun di SMA Negeri 4 Bandung, dalam menyajikan bahan ajar di materi syaja'ah ini, dengan menggunakan:

1. Powerpoint

Adapaun manfaat dari powerpoint ini adalah:

a. Untuk memudahkan Presentator mempresentasikan informasi 
Seperti salah satu kutipan di atas bahwa Microsoft Powerpoit ini digunakan untuk mempresentasikan informasi di waktu rapat, cara ini bisa membantu agar informasi yang di sampaikan bisa mudah dipahami oleh audiens.

b. Agar proses presentasi lebih tersusun

Pasti kita menginginkan presentasi yang memuaskan dan bagus, apalagi jika kita mempunyai klient yang penting, maka dari itu pesentasi kita harus tersusun rapih kita dapat menyusun dasn menuangkannya ke Microsoft Powerpoit tersusun di slide-slide yang tersedia dari mulai yang akan pertama kita bahas sampai penutupan.

c. Untuk membantu mengorganisasir informasi presentasi dan membantu dengan tampilan keseluruhan tampilan saat presentasi dapat terorgasnisir dengan baik karena di susun rapi berdasarkan point-point dari pembahasan pertama sampai teraskhir.

d. Materi yang di sampaikan menjadi mudah untuk di mengerti

Audiens akan lesbih cepat mengeti jika presentasi yang di sajikan menggunakan Microsoft powerpoint karena lebih simple apalagi jika di sertakan gambar contoh atau tabel pelaporan keuangan dan sebagainya.

e. Tampilan lengkap dan menarik memberi kesan wah saat presentasi

Sangat membantu dalam membuat slide, outline presentasi, menampilkan slide yang dinamis, termasuk clip art yang menarik dan semuanya akan mudah di tampilkan di layar monitor.

2. Video film

Materi syaja'ah ini merupakan ranah PAI bagian dari akhlak. Maka di sini para siswa bisa menyaksikan bentuk drama atau film dari video serta tayangan yang disajikan oleh guru di kelas. Untuk mencapai tujuan pembelajaran yang optimal sangatlah perlu menggunakan media sebagai alat bantu dalam proses pembelajaran Adalapun manfaat dari penayangan video film pada proses pembelajaran adalah sebagai berikut:

a. Sangat membantu tenaga pengajar dalam mencapai efektifitas pembelajaran khususnya pada mata pelajaran yang mayoritas praktek.

b. Memaksimalkan pencapaian tujuan pembelajaran dalam waktu yang singkat

c. Dapat merangsang minat belajar peserta didik untuk lebih mandiri.

d. Peserta didik dapat berdiskusi atau minta penjelasan kepada teman sekelasnya.

e. Peserta didik dapat belajar untuk lebih berkonsentrasi

f. Daya nalar Peserta didik lebih terfokus dan lebih kompeten.

g. Peserta didik menjadi aktif dan termotivasi untuk mempraktekan latihan-latihan.

h. Peserta didik dapat menayangkannya di rumah karena materi sudah dalam format film atau VCD.

i. Memenuhi tuntutan kemajuan zaman pendidikan, khususnya dalam penggunaan bidang media teknologi.

j. Memberikan daya pemahaman keterampilan yang lebih terstruktural. 


\section{SIMPULAN}

Bahan ajar adalah segala bentuk bahan yang tertulis seperti buku, majalah, koran, LCD proyektor, maupun bahan yang tidak tertulis seperti kaset, radio, film dan lain sebagainya yang digunakan oleh para guru dalam melaksanakan kegiatan belajar.

Adapaun manfaat yang dapat diperoleh apabila seorang guru mengembangkan bahan ajar sendiri, yakni antara lain; pertama, diperoleh bahan ajar yang sesuai tuntutan kurikulum dan sesuai dengan kebutuhan belajar siswa, kedua, tidak lagi tergantung kepada buku teks yang terkadang sulit untuk diperoleh, ketiga, bahan ajar menjadi labih kaya karena dikembangkan dengan menggunakan berbagai referensi, keempat, menambah khasanah pengetahuan dan pengalaman guru dalam menulis bahan ajar, kelima, bahan ajar akan mampu membangun komunikasi pembelajaran yang efektif antara guru dengan siswa karena siswa akan merasa lebih percaya kepada gurunya.

Secara umum bahan ajar dapat dibedakan ke dalam bahan ajar cetak dan noncetak. Bahan ajar cetak dapat berupa, handout, buku, modul, brosur, dan lembar kerja siswa. Sedangkan bahan ajar noncetak meliputi, bahan ajar audio seperti, kaset, radio, piringan hitam, dan compact disc audio 


\section{DAFTAR PUSTAKA}

Arsyad, Azhar. 2008. Media Pembelajaran. Jakarta: PT Raja Grafindo Persada

Djaramah, Syaiful Bahri dan aswan Zain. Strategi Belajar Mengajar. Jakarta: PT. Rineka Cipta. 2010

Harjanto. Perencanaan Pembelajran. Jakarta: Rineka Cipta. 2005

Majid, Abdul. Perencanaan Pembelajaran. Bandung: PT. Remaja Rosda Karya Offset. 2009

Prastowo, Andi. 2014. Panduan Kreatif Membuat Bahan Ajar Inovatif. Yogyakarta:Diva Press

Sadiman, Arief Sukadi dkk. Beberapa Aspek Pengembangan Sumber Belajar. Jakarta: Mediyatama Sarana Perkasa. 1988

Sanjaya, Wina. Perencanaan dan Desain Sistem Pembelajaran. Jakarta: Kencana. 2009

Sudjana, Nana. Dasar-dasar Proses Belajar Mengajar. Bandung: Sinar Baru Algensindo. 2009

Tim Pustaka Yustia, Panduan Penyusunan KTSP Lengkap Kurikulum Tingkat Satuan Pendidikan SD, SMP, SMA, (Jakarta: Buku Kita, 2007) 